\title{
The Unresolved Issues in Maritime Economics
}

\author{
Alexandros M. Goulielmos ${ }^{1,2}$ \\ ${ }^{1}$ Maritime Division, Business College of Athens, Athens, Greece \\ ${ }^{2}$ Department of Maritime Studies, Marine Economics University of Piraeus, Piraeus, Greece \\ Email: agoulielmos@bca.edu.gr, ag@unipi.gr,am.goulielmos@hotmail.com
}

How to cite this paper: Goulielmos, A.M. (2018) The Unresolved Issues in Maritime Economics. Modern Economy, 9, 1687-1715. https://doi.org/10.4236/me.2018.910107

Received: September 10, 2018

Accepted: October 26, 2018

Published: October 29, 2018

Copyright $\odot 2018$ by author and Scientific Research Publishing Inc. This work is licensed under the Creative Commons Attribution International License (CC BY 4.0).

http://creativecommons.org/licenses/by/4.0/

\begin{abstract}
Maritime Economics includes Port, Shipbuilding and Shipping economics with two important, but unresolved so far, issues/questions: 1) Is the vessel the firm (?) and 2) Is the tanker market perfectly competitive? These issues were thoroughly analyzed. There is also the opinion of Professor Button $\mathrm{K}$ (2005), about maritime economists, which we considered it necessary to evaluate. A review of Prof. Goss' paper on "early history of maritime economics" (2002), as well his entire contribution, is also carried-out as an obituary ${ }^{1}$ to his recent death. Reference is also made to Prof. Talley's research (2013) on "maritime economics" (2001-2012) in order to show the progress of this relatively new science of applied economics. Finally, the state of the tanker market, after 1987, and till 2010, is presented to connect past with present.
\end{abstract}

\section{Keywords}

Vessel as the Shipping Firm, Perfectly Competitive Tanker Market, Button's 2005 Opinion about Maritime Economists, Maritime Economics Research, 2001-2012, An Update of the Tanker Market, 1987-2010, Goss' Contribution as Obituary

\section{Introduction}

Prof. Tinbergen J started the economics of shipbuilding in March $1931^{2}$, while the economics of tankers established by Prof. Koopmans ${ }^{3} \mathrm{~T}$ in $1939[1]^{4}$ and ${ }^{1}$ He passed away on $8^{\text {th }}$ Feb. 2017, in Pershore, UK.

${ }^{2}$ Tinbergen (1903- ): a joint winner-with R Frisch, of the Nobel for econometrics (1969); he wrote about "shipbuilding cycle" (1931), using a mathematical model (found in selected papers, N Holland, Amsterdam, 1959).

${ }^{3}$ Koopmans (1910-1985) received a Nobel in 1975 (with Kantorovich) for Planning.

${ }^{4}$ Prof. Emer. Molenaar H J., graduate of the "Netherlands school of Economics" (1951) continued the tradition; his doctorate was on: "Speed selection for tramp and liner vessels". He joined UNCTAD (1966-1968). Head: 'Maritime research Foundation' (Hague; 1968-1976). He convened an international symposium on shipping economics (Hague) (1970). Professor: in Erasmus University (1984-1991). 
continued by Prof. Zannetos Z [2] of MIT (1966). Late Prof. Goss ${ }^{5}$ established Maritime Economics in Britain (1963). Notably, Goss complained [3] that Britain-a traditional great sea power-created no shipping economics' school ${ }^{6,7}$. Moreover, Goss appointed shipping consultant to British government and edited (1981-1991?) “Maritime Policy \& Management” journal (1973)

Goss presented 7 of his papers (published in 1963-1967), within two covers, (1968) [3], dealing with the "efficiency" of sea transport". At the same time, Prof. ${ }^{10}$ Sturmey S (1962 [4]) appeared, who worked for UNCTAD's “Committee on shipping", formerly at the University of Lancaster, and Mrs. O' Loughlin C (1967) [5]), wrote a textbook on shipping economics.

Goss argued that Maritime economics is the discipline "embracing seaports, and the activities of ships in seaports, and (of) ships"... [6]. In addition, Port economics due to him, we believe, expanded by leaps and bounds, producing by 2013, 3\% more papers than Shipping economics...

Goss established Port Economics in Britain (1977). He, during 1977-1978, visited 40 seaports to report about their structure, management, administration, economics etc. What is not widely-known is that Shipping economics includes economics of shipbuilding ${ }^{11}$. Sturmey (1962) [4] e.g. (p. 9) found it necessary to explain why he omitted any specific discussion on shipbuilding...

Goss attempted not only to define some of the principal problems of this field, but also to "measure" them [3]. This was an early idea of Maritime Econometrics, we reckon, on which Evans and Marlow (1986) [7] —closer colleagues of Goss-published a relevant book. In the meantime, Goodwin and Kemp (1979) $[8]^{12}$ published a book on Marine Statistics.

Goss edited (1977) [9], under two covers again, 8 papers-of which 5 of his ${ }^{5}$ Goss received an honorary doctorate from department of Maritime Studies University of Piraeus (in 1999).

${ }^{6}$ Two maritime economics' schools established: one by Professor Georgandopulos E $(1953 ; 1959)$ at University of Piraeus; who, after 1967, joined UNCTAD. In 1978-1979 published 2 papers in Bremen institute in shipping economics: lectures and contributions, 1 in "MP\&M" in 1986 and 1 in "Marine Policy" in 1988. Prof. Svendsen A $(1955 ; 1958)$ in Norway established the $2^{\text {nd }}$ school. Georgandopulos' 1959 book titled Maritime Economics. He organized the 1st international Maritime economists conference (in 1976) (in Piraeus). Prof. Metaxas B, former at Ealing Technical College in UK, (who passed away in 1996), continued the Greek maritime tradition appointed Associate Professor in Piraeus.

${ }^{7}$ Prof. Haralambides H in late 1980s elected lecturer at University of Piraeus, Dept. of Maritime Studies, presently Prof. at Erasmus University and editor of Maritime economics \& Logistics journal. Doctorate: "The shipping account in the Balance of Payments: the case of Greece", University of Wales, 1985.

8"MP \& M" initially covered Marine Economics. Since 1981 papers on it ceased. "Marine Policy" journal published in Cardiff in 1976 covering partly the same subjects as MP \& M.

${ }^{9}$ Goss meant "cost" and how to get it down.

${ }^{10}$ Sturmey [4] showed: "why UK register declined from $~ 45 \%$ of the world total (1900) to $~ 16 \%$ (1960)"? Because: since World War I, British shipowners did not modernize their fleets as fast as their competitors: adopting diesel, higher speeds and using cheaper shipbuilding (abroad); they neglected tankers and standardized cargo vessels; there was no self-criticism. Industry rested on its past glory; British shipping family-companies kept company's control in house-using self-finance-exploiting the "conference system", and maintaining status quo and be inflexible.

${ }^{11}$ This branch is neglected, but revives at times.

${ }^{12}$ Veenstra A W (in 1999) awarded a doctoral thesis from Erasmus University, titled: "A quantitative analysis of Shipping Markets", published by Delft University Press. 
own or with co-authors. He talked again about British for not creating an English maritime school... but the situation in 1977 was different from that in 1968, as not only a lack of a maritime schools till existed, but Goss's complaint was now for the lack of valuable books on maritime economics and finance. These were, indeed, needed for the very larger ship sizes appeared needed substantial bank finance and implied high risks, unknown before.

Shipping's fast growth after II World war, and till end 1973, was based on... other people's money (Onassis) (Goulielmos, (2017a) [10]), especially in tankers. He exploited economies of scale with tankers called "supertankers" for the first time (1938) (Goulielmos, (2017b) [11]). Recognizing this need, half dozen books on shipping finance published (e.g. Stokes P., (1992) [12]).

The changes mentioned were: the publication of the journal "Maritime studies $^{13} \&$ Management ${ }^{14}$ " (1973); more people started to publish maritime articles out of research; the establishment of honors and other degree courses ${ }^{15}$ in maritime economics in UK. However, the overall lack of supervisors, beforemid-1970s, greatly delayed the progress of the discipline.

Paper's structure is as follows: next is a literature review. Part I reviewed Prof. Thorburn's theory ((1960) [13], p. 11) arguing that the vessel is the unit on which investigation exclusively (had to be) based; she has to be the economic unit of analysis (=shipping firm), while the shipping firm per se... is supposed to play a subordinate role (italics added). This theory adopted by Prof. Zannetos in 1966 [2], who failed to realize that things changed since 1960, and to update his doctoral thesis when published in 1966.

Indeed, management of shipping firms changed during 1960-1970, where "shore offices" of shipping companies obtained full power over the vessel (Downard, (1984) [14]). Technical knowledge increased, communications greatly improved and control techniques applied, together with the appearance of a quite number of powerful shipping departments. Shipping firms were not single-ship ones anymore and the owner stopped to sign on board. Management by distance started.

Followers of Zannetos slipped into the same mistake, i.e. to consider vessel as the firm: (Evans, (1994) [15]; Veenstra and La Fosse, (2006) [16] and others). Further, Talley, (2013) [17]) claimed to have proved that: "if tanker markets operate as perfectly competitive, the free entry and exit of ships-taken as firms-cause cyclical freight rates"...

Part II dealt with the exact "form" of the tanker market. All statements of maritime economists ${ }^{16}$ are remarkably vague over their effort to affirm that tanker market is "perfectly competitive": "shipping markets are like or as if, or can be,

\footnotetext{
${ }^{13}$ Older maritime economists had an obsession with "maritime studies", instead ... of "maritime economics".

${ }^{14}$ Re-titled "Maritime Policy \& Management".

${ }^{15}$ In University of Wales, in Southampton College, and polytechnics: in the City of London, Liverpool, Plymouth, and Sunderland; also the "Marine transport center" in Liverpool established.

${ }^{16}$ Binkley and Bessler, (1983) [18]; Norman, (1979) [19]; Glen, (1990) [20]; Evans, 1994 [15]; Veenstra and De La Fosse, 2006 [16] and others.
} 
near, or approaching... perfect competition"... Zannetos [2] argued similarly, but for him the whole issue was a paradox (p. 190), which he wanted to understand...

Part III dealt with Goss' (2002) seminal paper [6] concerning "the growth and flowering of maritime economics, as a recognized discipline". Part IV consists of a summary of the evolution of maritime economic research (2001-2012) due to Talley (2013) [17]. Part V cleared-out the boundaries of the 4 sub-disciplines: "shipping (including cruising), shipbuilding, ports and marine economics". Part VI built a bridge between Zannetos' writings till 1987, and the most recent developments in tanker economics, till 2010, as structural changes since end-1973 took place after the two energy crises in the tanker market.

Appendix dealt with Prof. Button's (2005) [21] paper, which, we thought, needed an answer. He looked into the "degree to which maritime economists really understood shipping economics" (italics added)...! He argued that economic drivers behind shipping remained relatively poorly understood... He wanted to introduce Coase's R (1910- ) (1998) [22] theory into shipping...He wrote that shipping economists (1985-2005) possessed a better understanding of many of the underlying relationships ... than their colleagues before, but for Button persistent gaps remained, due to technological and institutional changes.

\section{Literature Review}

Goss was proud for the report of the "UK Committee of Inquiry into shipping" [23], in which he was economic advisor. Goss (1965) [24] argued that before 1957 studies of alternative ship designs lacked explicit criteria for comparison, and in 1970, he published-with Jones-and for the "board of UK Trade" — work on "size economics of dry bulk carriers" (Goss) [25].

Goss inclined towards, and had a stronger challenge from, port economics, than shipping economics, we reckon. This is why we recognized him as the founder of port economics. He early interested (Goss, 1967a) [26] in the "cost-benefit" analysis applicable to ports ${ }^{17}$ and the "turnaround of cargo liners and its effect on sea transport costs" (Goss 1967b) [27].

Moreover, Goss' work (Goss, 1990a) [28] used by "World Bank" to create a "generic port model" - the "port Reform Tool Kit" (prior to 2003) ( $2^{\text {nd }}$ edition in 2005) (Brooks and Pallis, (2012), p. 491 [29]) — to create an appropriate one for port governance-and ... “public goods”. Goss (1990b) [30] argued: if a lower service time and cost are passed to society, they will lead to the ultimate public goal, so that port investment to increase producers' surplus from exports and consumers' surplus from imports (Dekker and Verhaghee, (2012) [31]).

Goss commented [32] on the paper presented by Lorange P and Norman V D

${ }^{17}$ It may sound nowadays strange for such a technique to attract the interest of Goss; but it is true that neither ports, nor shipping companies, used investment evaluation methods before 1973. Large investments in the main ports of Belgium, e.g., used no investment evaluation methods and this was also true for shipping companies. For Belgium: see Jan Strubbe, (in 1987), The Ports of Belgium: a heritage for the future, Lannoo, ISBN 90209 14987; for shipping: Goulielmos (2017a) [10]). 
"risk preference and shipping decisions", during a seminar in Bergen and aware of the work of Koopmans (1939) [1] and Zannetos (1966) [2], argued that tanker markets obey ${ }^{18}$ a "cobweb" model. Tankers are characterized by very large rate fluctuations, in the short term, connected with new ships through the acceleration mechanism. He mentioned that banks looked for equity participation in shipping finance (due to increased risks) and he denied that large ships are generally more risky, been more profitable (Goulielmos, (2013a) [33]).

Veenstra and De La Fosse (2006) [16] argued that Goss (1972) [32] mentioned Zannetos in connection only with "freight rate" analysis, and only once in his 2002 paper [6]... His apathy triggered authors to provide an insight into the way maritime economists "see" one another...but they failed to continue this interesting work.

In a voluminous book ${ }^{19}$ on Maritime Economics, Goss is mentioned only 7 times... Heaver (2012) [34] provided an interesting historical evolution of maritime economics. With reference to the foundation of maritime economics, as an explicit field of study in 1962, Heaver quoted Goss (2002) [6], saying that before 1960, maritime economics was almost non-existing...

Matters dealing with the insurance of ships and of cargoes also remained by 2003 outside the beneficial study of maritime economists (Goss, 2003 [35]). Heaver (2012) [34] argued that maritime economists were interested mainly in markets' behavior, studying the-near perfect competition-charters, and the cartelized $^{20}$ liner market (Marx, 1953 [36]) (italics and bolds added).

\section{Part I: Vessel as the Shipping Firm}

\subsection{The Representative Firm}

In Microeconomics, and since Marshal (1920) [37], the concept of "representative firm"-RF, appeared ${ }^{21}$. RF behaves like the majority of firms: has a technology of the same returns to scale, price-taking, gaining zero profits at equilibrium in the long run, and having a unique optimal capital-output ratio. RF equalizes price with average cost-AC, producing less than perfect competition (Evans, (1994) [15]). All RF have identical demands, revenues, cost functions and initial price-quantity combinations; they sell the same product, and have the same maximizing behavior. The reaction has no effect upon competitors (Henderson and Quandt, (1958) [38]).

Zannetos [2], we believe, assumed that the "marginal ${ }^{22 "}$ vessel is a $\mathrm{RF}$ in the tanker market. As a result $\mathrm{AC}=\mathrm{MC}$.

\footnotetext{
${ }^{18}$ This argued first by Zannetos [2].

${ }^{19}$ The "Blackwell's companion to Maritime Economics", (in 2012), edited by Talley, 735 pages...

${ }^{20}$ British first established a cartel in the liner sea transport between India and UK in 1875.

${ }^{21}$ Marris R argued in "Economic Journal" that "the firm is the unit of delegated authority in a decentralized productive system" (p. 321: in his "why economics needs a theory of the firm", in Supplement, 1972).

${ }^{22}$ Marginal vessel is the one having the higher average cost-a threshold-and she is the first to exit in a shipping crisis.
} 


\subsection{Short and Long Runs}

Given the definition of Marshallian short-run one in shipping gets confused, as short-run in shipping can be indeed very short in calendar time: $\sim 1$ month, as the is the minimum time for a shipping company to scrap, sell or buy a vessel, and thus change its capital.

For shipping industry, short-run can be, also, very short, equal to the minimum time to scrap a vessel. The delivery time of a newly-built ship-which too changes industry's capital-surely varies from a minimum of 1 year to a maximum of 2 years, and this depends on the phase of shipping cycle and shipbuilding technology. So, in shipping 3 long runs exist...one for the firm and two for the industry...

Our theory is that shipping firm is always in the long run. Evans (1994) [15], argued that in the long run the market is less efficient and a single market price does not exist?

\subsection{The Shipping Firm $=$ The Vessel?}

Zannetos (1966) [2] argued that "the shipping firm is the vessel". This perception, we believe, is based on shipping in periods of difficult or very slow international communications, with no faxes and mobile phones. Captains-by necessity-before 1960s, used to take almost all ship's decisions, where not only Captain, but also Owner was on board. Distance intensifies today control instead of weakening it-as Zannetos believed-given also the serious amounts ${ }^{23}$ being at stake nowadays.

Zannetos (1976) [39] argued that the theory of value under uncertainty and certain theoretical reasons-not mentioned-dictated that the vessel operates like a firm'... (bolds and italics added).

The absence of large administrative and financial optima permit vessel to operate as the firm, he argued. But there are such optima at least in forms' size, we reckon, which vary according to owner's personal preference. The majority of Greek shipping firms are family or personal (Goulielmos, (2017b) [11]). So, the important issue of firm's size, (number of ships), is a subjective matter, depending on owner; but a shipping firm can be indeed very big as there are no limits in shipping, except those put by prudence (there is the Zissimatos case ${ }^{24}$-of "Adriatic tankers"-who owned 111 ships and Colocotronis' case who ordered 2 VLCC) (Goulielmos, (2017b) [11]), who both failed.

\subsubsection{Shipping Firm = A Multi-Plant-Vessel Firm?}

For us, a shipping firm is a "multi-vessel" firm (Figure 1), "a set of vessels". Captain has to obey to shore-office's written instructions (formalization) and oral ones, supervised closely by the operators of company's operations department. There is a strategic center with many isolated floating factories.

The above (hypothetical) shipping firm as 3 vessels with 3 different average

${ }^{23}$ The amount embodied in one ship can be over $\$ 200 \mathrm{~m}$.

${ }^{24}$ Couper (1999) [40]. 


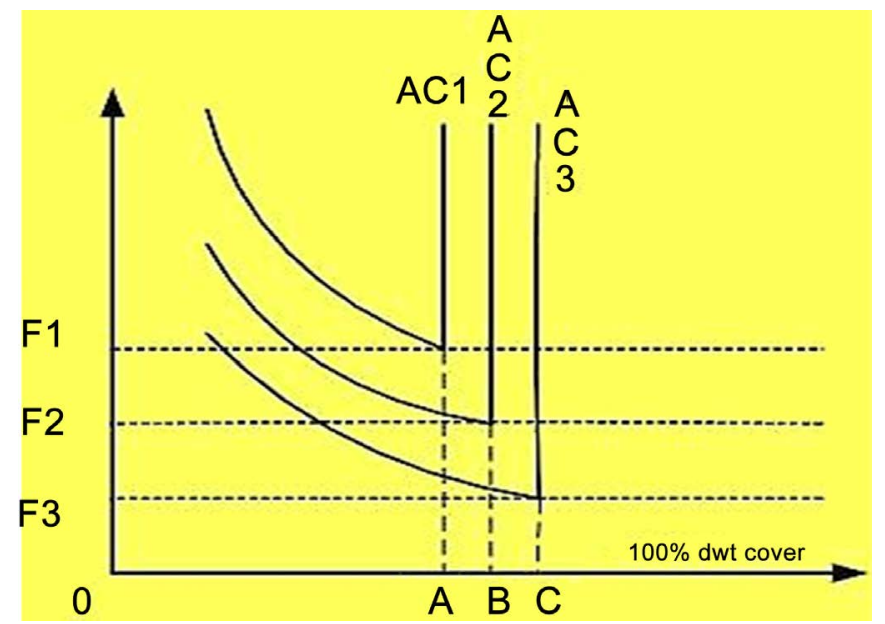

Figure 1. Equilibrium of a shipping firm with 3 vessels. Source: author.

cost curves $\left(\mathrm{AC}_{1-3}\right)$. To earn "normal" profits (for all vessels), freight rate should be $0 \mathrm{~F}_{1}$. The 3 vessels have different production (in ton miles), and given that $0 \mathrm{~A}$ $<0 B<0 C$, they embody economies of scale. Which vessel is the firm? All 3 ...we believe.

For Zannetos [2] every vessel, and also that having the $\mathrm{AC}_{1}$, is the firm (p. $145)^{25}$, though owned by the same firm-a multi-firm case. Her AC is a proxy of her $\mathrm{MC}^{26}$. Production at $0 \mathrm{~A}$, assumes $\mathrm{MC}=\mathrm{MR}$ (not shown), given demand.

By adding 2 vessels to the firm, production increased, and assuming lower subsequent costs of the two added vessels-as newer and larger-production is more profitable at $\mathrm{MC}_{1-3}=\mathrm{MR}$, given demand.

For Zannetos, all ship costs are equal and all ships are of equal size... Obviously his theory deprives a shipping firm from higher profits, from higher production and from economies of scale, as shown.

Moreover, Management is where decisions are taken, i.e. at shore office. The manager in "a multi-vessel shipping firm" obviously cannot be at all ships at the same time $e^{27}$... Each ship earns profits and suffers losses, contributing positively or negatively to firm's overall net profit. A firm "cross-subsidizes" its ships. Profitable ships "compensate" unprofitable ships in the short run. Vessels are cost-based units and price-takers.

Vessel's production varies from voyage to voyage (one way); voyage is the unit of production $\left(\right.$ Evans $^{28}$, (1994), [15], on which MC has to be calculated; vessels provide many "productions" in the unit of time (say one year), bad and good, as the case may be. As a result MC varies per voyage... This is why a new branch ${ }^{25}$ In 1948-1953 her size was 12,000 dwt and in 1954-1958 was 16,500 dwt.
${ }^{26}$ Vessel's MC is the cost added to total cost from an additional voyage (one way); economic speed
influences cost depending on price of fuel etc.; distance must also be taken into account. Port costs
should be included, despite the difficulties encountered by Evans (1994) [15]. One must include also
time at sea and in ports as they affect the end result. Evans argued that MC (of a voyage) = fuel cost
$+\left(\mathrm{TCE}{ }^{*}\right.$ voyage time)... where TCE = time charter equivalent. MC in shipping unfortunately has
many definitions...
${ }^{27}$ A result of the greater size of shipping companies in terms of number of ships owned.
${ }^{28}$ Evans [15] argued that it is possible to determine a 'MC function' for a given voyage (p. 319)... 
has been established in certain Academia called: "Vessel's economics".

Moreover, vessel's expenses are planned by the shore office, and are written-down in firm's budget. Ship's serious repairs are not carried-out by crew anymore. Ship's chartering ${ }^{29}$ is also a matter of the shore office, and her supplies, insurance and recruitment. Ship's finance is dealt by company's manager personally. Captain receives funds from the firm to pay ship's expenses (crew wages etc.), and he is accountable for this, submitting detailed account every 2 months to the head office (MGA). He is not independent.

\subsubsection{Zannetos' Theory about Vessel Being the Firm ${ }^{30}$}

He argued that "mobility" and "ease of entry" are (p. 182 [2]) the properties that make a vessel to be the firm, and...there is absence of an "effective central control"... due to distance; timely decisions have to betaken at vessel's level; "Captain is the law"; the "vessel", administratively, "is the firm". Planning is done on a vessel by vessel basis.

Zannetos wanted to equalize company's MC-i.e. the cost of marginal vessel-to vessel's charter rate, i.e.MR. Otherwise he had to add costs and revenues per voyage, required for his analysis-something impossible. If Zannetos had a difficulty in finding MC, he could use $A C$ at equilibrium, where $A C=M C$, and where AC is known... (Besanko et al., (2013) [41]).

The size of a shipping company can temporarily change-via the lay-up process-(= ship's shut-up), but ships' sizes usually remain fixed (though technically can change) in the short run. Ships stop more easily producing, but company's bankruptcy is more difficult and more time-consuming. Shipping companies exist even when own no ships, for even as long as say 3years (our experience from Greek shipping). The vessel is laid up when her MR equals her $\mathrm{MC}$ and the average variable cost-AVC (Figure 2).

Ships seek to maximize the difference between total revenue-TR (tons transported at net freight rate-i.e. after deducting brokers' commission-over a specific distance at their economic speed) and total cost-TC, paying a \% for firm's administration.

As shown, freight rate is determined by Supply and Demand (0F1) for the industry. At $0 \mathrm{~F} 1$, vessel maximizes her profit $(\mathrm{AC}=\mathrm{MC}=\mathrm{AR}=\mathrm{MR}=0 \mathrm{~F} 1)$, provided her dwt is fully used (95\% in practice). The AC and MC of the vessel are initially falling, till they reach the " $\mathrm{dwt}^{31}$ limit", where afterwards both costs rise vertically. This wants to indicate that after vessel is fully loaded, no additional cargo can be accepted.

If a new-building enters the market ( $\rightarrow \mathrm{SS} 2$ ), ceteris paribus, the freight rate ${ }^{29}$ Zannetos got it all wrong saying that: the vessel has "independent" employment; absence of any "administrative superstructure"; her fixed costs can be ignored; she has a very small optimum size-ignoring economies of scale...

${ }^{30}$ Evans (1994, [15] p. 312) argued-but not convincingly but not convincingly that "since cargoes and ships are scattered over the globe by distance, as well as by time, the individual ship must be considered to comprise the establishment' or "firm" and, "with certain exceptions", "a shipowner with a fleet of 20 - 30 ships is not normally in a position to exert any influence on market" (italics added)...

${ }^{31}$ Bunkers and water etc. antagonize cargo for the same space; ship cannot get additional cargo if her load lines are reached. 


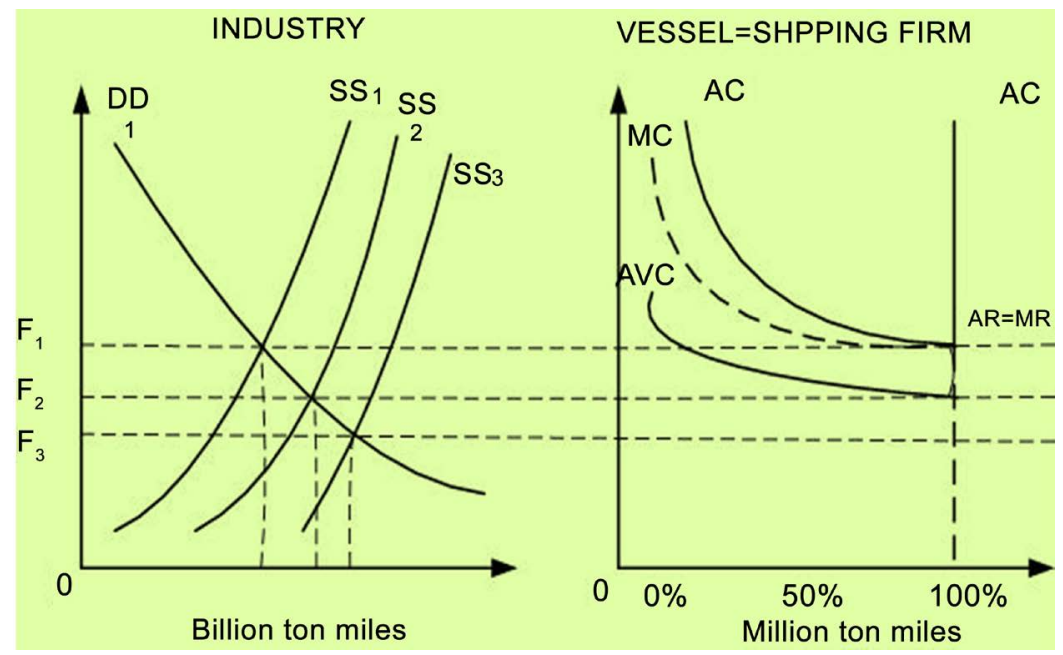

Figure 2. Equilibrium of a shipping firm "as a vessel”, and her industry. Source: author.

will fall to $0 \mathrm{~F}_{2}$, and the vessel there will cover only her AVC. If further deliveries of new buildings take place-and scrapping and laying-up of existing ships are inadequate to counteract Supply's rise-the freight rate will further fall to $0 \mathrm{~F}_{3}$. Ships then will be removed-temporarily-away from an unprofitable production.

At $0 \mathrm{~F}_{3}$ the vessel (Figure 2) has to be laid-up. At $0 \mathrm{~F}_{3}$, the lay-up cost/day is less than voyage and operating cost/day. This loss from chartering is greater than the expenses of laying-her-up. The time of deciding about laying-a ship-up varies in practice; this decision to be taken may take about maximum 3 years from the specific time when freight rate is at $\mathrm{OF}_{3}$, and is expected to remain there. In shipping, the time, for the ship to remain in lay-up, determines the total lay-up cost, as this is a function of time; this will end at the moment ship is scrapped, sold or restarts.

Professor McConville ${ }^{32}$ J. (1998 editorial, MP \& M [42]) disputed ${ }^{33}$ the possibility of an equilibrium in maritime economy...for the obvious fact that shipping markets - at his time-..- did not clear.

\subsubsection{The Supply of a Shipping Industry with 3 Vessels}

If the industry consists of 3 vessels - as assumed above - and their AVCs =ACs, the supply curve of the industry will be a straight line, S (Figure 3).

\section{Part II: The Form of Tanker Market}

\subsection{Zannetos' Theory Supporting a Perfectly Competitive Tanker Market}

Zannetos concluded: the tanker market could display perfect competition if MC ${ }^{32} \mathrm{Ph} . \mathrm{D}$ : Warwick University (1982) on "shipping industrial relations in UK". He published: "Economics of Maritime Transport", (1999), [44] and the "bibliography of maritime economics and shipping business" (1995) [45]; editor of Maritime Policy \& Management (1992-2002?). He specialized on "manpower and labor issues" since 1977. In 1983 published-with Calvert J-the "shipping industry statistical sources".

${ }^{33} \mathrm{He}$ was not the only one after the 2008 meltdown. 


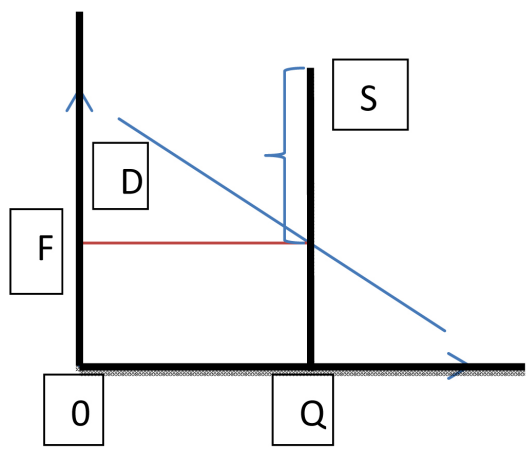

Figure 3. The supply curve of a ship space for hire or voyage is the part of MC above AVC (not shown). Supply is absolutely inelastic.

$=$ MR. But as argued by Lerner ((1934), [43], p. 161), the condition MC $=$ MR is always valid at equilibrium in all types of markets.

Zannetos' main aim [2] was not only to prove the existence of "perfect competition" in tanker market, but also to solve this paradox: how is possible for the tanker freight rates and the demand for tankers to be cyclical, while the demand for (oil) transport is not? Zannetos (p. 243 [2]) argued: "tanker markets, paradoxically, operate in a fashion resembling perfect competition" (italics added).

Zannetos [2] was not satisfied-quite correctly-by Koopmans' conclusion ${ }^{34}$ that the freight rate cyclicality was the result of "ship replacement" cycle, as manifested by the actions of Norwegian shipowners at his time and by the work of Einarsen J (un-dated ${ }^{35}$ ). Zannetos rested on the "mobility ${ }^{36}$ of capital" to equate supply to demand; but this is a condition of equilibrium, not of competition; and also he argued that there is "absence of excessive artificial national and international controls ${ }^{37}$ contributing to a perfectly competitive climate" (italics added).

Zannetos (p. 243 [2]), moreover, required the existence of the independents (private owners); but most independents-as he stated-were not in the market, they were in ownership... and logically if they were not in the market, they had to be... in negotiations, we believe.

${ }^{34}$ Koopmans argued (p. 159 [1]) that the tanker freight market inherently developed cyclical movements due to construction time and the close connection between momentary freight rate and building orders (p. 160 [1]). Demand is cyclical, independent and uncertain. Koopmans criticized correctly Tinbergen's mathematical model (p. 163) [1], assuming uniform cycles up and down, while booms are shorter. Koopmans used [1] a non-linear supply curve. But between 1988 and 1997 the peak lasted10 years (Stopford, 2009 [46]). For Koopmans (p. 165 [1]), the cycle-generating mechanism is due to the fact that ships are few when needed, and many, when not! He said that in 'new tanker tonnage' contracted, the most decisive influence is exerted by expectations (p. 158 [1]) about the degree of equilibrium between demand and supply in the next few years. These determine freight rates.

35"Reinvestment cycles and their manifestation in the Norwegian shipping industry".

${ }^{36} \mathrm{We}$ believe that the possibility of laying-ships-up, and scrapping them, equalizes-out supply and demand during a depression, and also by un-laying-ships-up in the short run, and by increasing them through shipbuilding in the long run, does the same during a boom.

${ }^{37}$ Things changed since 1966 with the appearance of ISM Code in 1998/2002 and various international conventions, especially MARPOL 1973, and its amendment in 1978 and afterwards. 


\subsection{Zannetos Rejected Oligopoly}

Zannetos (1966) [2] rejected the possibility for the tanker market to be oligopolistic. He argued that the concentration of tanker owners in the spot market, at any one time, is small in terms of capacity, and there one can find only the independents (p. $174[2])$. The argument, however, of a tiny (4\% - 18\%) presence in spot market at Zannetos' time, can be turned round against him, because when economists say "many" buyers in a competitive model, they mean, we reckon, in the market, not outside it!

If Zannetos was right, then, we reckon, something between $38 \%$ and $62 \%$ of total available capacity had to be chartered "elsewhere", not in the spot market, in the long run. Zannetos insisted, however, that tanker rates are determined under conditions approximating perfect competition, as the transport cost is an input to oil, where CIF price of oil $\neq$ MC (p. 10, [2])...

\subsection{Oil Companies: Oligopsony?}

An oligopsony maximize profits, as all firms:

$$
\text { Profits }=\mathrm{P}(\mathrm{Q}) \mathrm{Q}-\mathrm{T}(\mathrm{Q}) \mathrm{Q}
$$

where "revenue" is $\mathrm{P}(\mathrm{Q})=\mathrm{CIF} \times \mathrm{Q}$ (from oil), which is reduced by transport cost $\mathrm{T}$, i.e. freight rate $\mathrm{T}$;

$$
\mathrm{dProfits} / \mathrm{dQ}=\mathrm{P}+\mathrm{QdP} / \mathrm{dQ}-(\mathrm{T}+\mathrm{dT} / \mathrm{dQ} \mathrm{Q})=0
$$

for a maximum. The reduction of "transport cost" is desirable: profit $=$ Price $_{\mathrm{CIF}}$ - C-I-F, where $\mathrm{C}=$ the cost of crude oil at its well, $\mathrm{I}=$ transport insurance cost, and $\mathrm{F}=$ transport cost. The cost of crude oil and the insurance cost must also be managed - the first to rise, but this is mainly determined by OPEC-and the second to fall, by negotiations with insurance companies.

In our opinion (Goulielmos, 2013b [47]) independent tanker owners did not negotiate with oil companies for a freight rate equal to spotrate-which would have no meaning-but for their long run AC, through new-buildings, which had to follow after negotiations. Independents, we believe, were more efficient tanker owners than oil companies, where later were also shipowners.

\subsection{What Is the Supply and Demand of the 7 Oil Companies Being the Sole Buyers of Independent Tanker Services (Figure 4)?}

MR is the amount of net "revenue" of oil companies by chartering an additional ton from independents. This is the MP-marginal product-of tonnage chartered times MR from oil transported. This falls as more tonnage is hired. Supply is rising, because higher rates attract greater number of tanker owners (independents). At the competitive equilibrium, 01 of tonnage will be employed at a freight rate 02 (Figure 4).

Oligopsony will hire 03 tonnage and pay $04(<02)$. So, it pays to be oligopsony. Pure oligopsony is a market where buyers are few; pure means to be free from elements of monopoly. Moreover, Lerner (1934) [43] defined pure competition, if there is freedom from all elements of monopsony... 


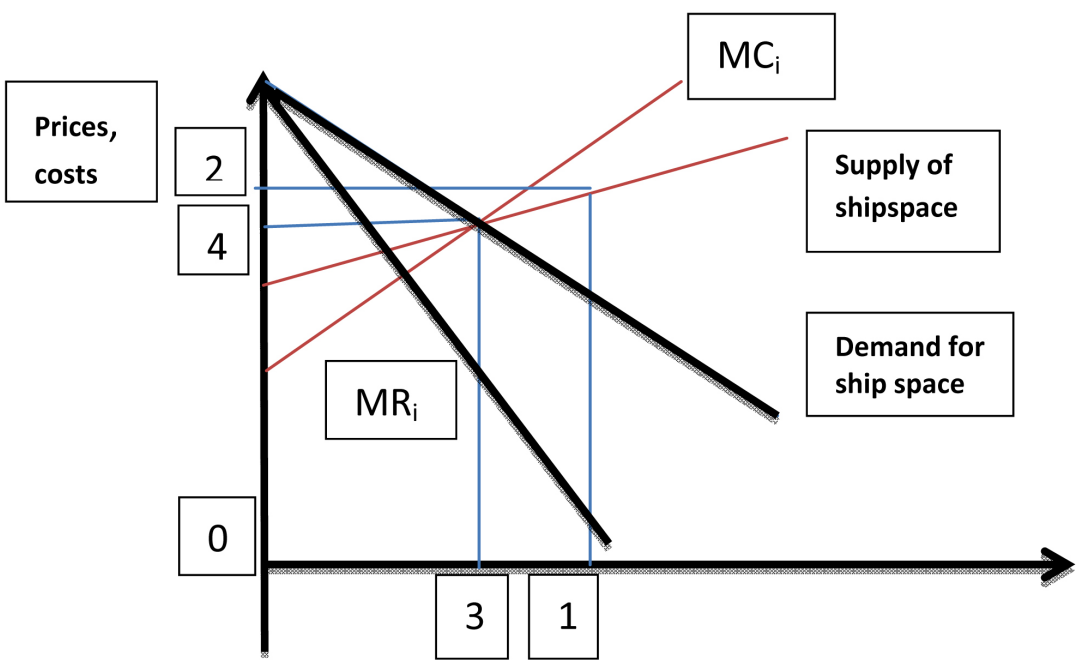

Figure 4. Oil companies as oligopsony. Source: Inspired from Hirschey et al., (1995) [48]; Martin (2010) [49]; Morrison (2001) [50].

\subsection{Did Oil Companies Boost the Supply of Independent Tanker Owners?}

The reduction in transport cost can also be done in a legitimate and clever way by "increasing" supply (Figure 5): here "with one stone 2 birds can be killed"...

Oil companies negotiated with each large independent tanker owner a long-term charter, assuming that new tonnage will be next built. This had as a result to increase supply, or absorb demand-before going to market—and thus reduce the cost of oil transport (freight rate) payable by oil companies.

The independent owners in order to achieve the lowest transport cost possible, and at the same time increase their profits, resorted to "exceptional" "economies of scale" (e.g. Onassis). Thus the freight rate payable by oil companies had two pressures downwards: one from new tonnage built and one from the larger sizes of new-buildings.

\subsection{Zannetos: Victim of a Definition?}

Zannetos was a victim-we believe-of the definition that exists-till this day-for "concentration", where oligopsony's power is measured by the "degree of concentration". When Zannetos looked in the spot market ${ }^{38}$, he found no independent owner-oil companies were absent-owning more than $1 \%$ of available capacity at any one moment...(p. 176 [2]), so he concluded that tanker (spot) market operates "perfect competitively" (p. 182 [2])...

He also said something reversing his original position (p. 176 [2]): that anyone who has a disposal more than $3 \%-4 \%$ of total capacity, can very effectively exercise "price leadership" and "organize" the market... Do certain oil companies have that \% today? Shell had $12.24 \%$ share in 2002 in all charters in dwt and 12 other companies had $>3 \%$ (part VI).

${ }^{38}$ Spot market was very thin for Zannetos, consisting from $10 \%$ to $15 \%$ of total capacity (p. 184 [2]). This $\%$ varies over his various publications, e.g. from $4 \%$ to $18 \%$. 


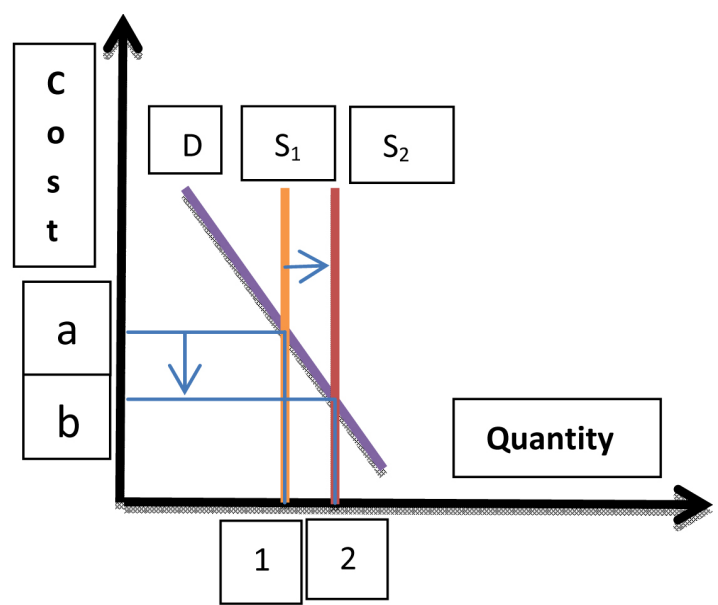

Figure 5. Long term charters. They lead to an increase in supply from 1 to 2 and a lower transport cost for oil companies from a to b. Source: author.

\subsection{The Ownership Tanker Pattern}

Oil companies did not increase their ownership after 1975, from 36\% since 1950, but only provisionally in 1980 and in 1985 , to $40 \%$; finally this fell to $21 \%$ in 2000 from 30\% in 1991 (Figure 6).

The ownership \%-despite Zannetos 1973 [51] warning to oil companies-fell further to $6 \%$ in 2003 . Why oil companies kept at a certain fixed \% of ownership round 33\% for decades in the first place? Zannetos (1973) [51] provided an indirect answer: "oil companies had to step into the market to acquire ownership control of a substantial part of the necessary transportation capacity"... because ownership controls the market'. If this was true, can then be perfect competition?

\subsection{How Much Pure Is "Pure" Competition?}

The issue of how much "pure" is pure competition in tanker market remains obscure. We admit that the number of tanker owners (independents supply $81 \%$ of total tonnage now) is higher, but we also saw-as mentioned-that one shipping firm of a serious size can influence supply through a large ship building order. We have also the example of "Sanko" in 1983 (Couper, (1999), p. 37-8 [40]) in newly built bulk carriers of $3.5 \mathrm{~m}$ dwt and "Eletson" in the case of newly built Product carriers of $1 \mathrm{~m} \mathrm{dwt}$, which influenced freight market.

Zannetos argued (p. 182 [2]) that "the tankship market operates in a manner approaching perfect competition", by stating in a row the 3 classical arguments: "free exit", "free entry" and "mobility", which encourage competition (italics and bolds added). Zannetos argued (p. 99 fn. [2]) that between 1954 and 1957 oil companies controlled between $80 \%$ and $91 \%$ of total world fleet (=supply)-by using ownership, time charters, and consecutive-voyages... Tanker markets despite they behave in a "nearly perfectly competitive manner"-Zannetos (p. 190) [2] argued-not all preconditions of perfect competition exist-a paradox (italics in the original)... 


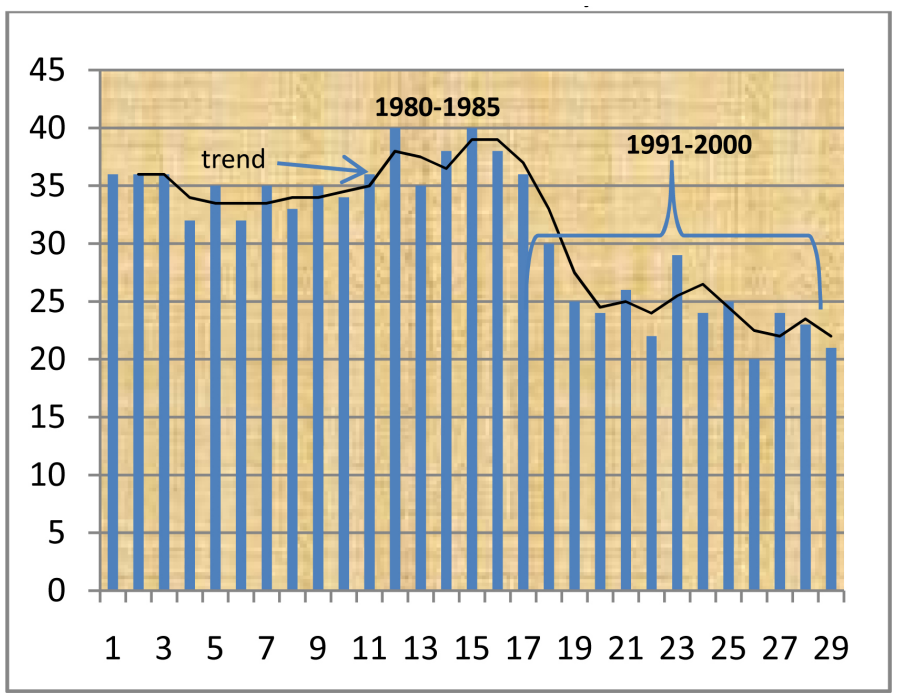

Figure 6. Ownership \% of Oil companies in dwt, 1950-2000, various years. Source: Data from J. I. Jacobs \& Co Ltd, various semesters. Graphed: by Author.

\subsection{Zannetos' Cycles... Proved by Talley?}

Talley (2013 [17])... proved-something missing from the literature, as he argued. This was his way tanker market displays cycles a la Zannetos. Talley's diagrammatic proof is shown in Figure 7.

Figure 7 shows equal up and down shifts of a straight line supply crossing a constant straight line demand. This is a comparative-statics analysis, which cannot display dynamic cyclical effects as did Zannetos with his figure below Figure 8 . To be realistic when one deals with shipping cycles he/she must allow for booms shorter than depressions.

Zannetos (1966 [2]) based his analysis about cycles on "expectations theory" due to Hicks (in 1946). He said ([2], p. 44): if expectations are elastic, the cycles need first an initial push. If rates rise, they will generate inter-period substitution. Expectations shift demand, and increase rates... This holds till expectations change, or new deliveries shift the supply. If rates fall, elastic expectations re-start; orders will be postponed and depression will continue.

Cyclical demand is not necessary. Rates change and affect expectations, and expectations influence cycles. Talley (2013 [17]), therefore, had to modify Zannetos' expectations theory first and then show his equilibrium.

Figure 8 represents actual Zannetos' theory; we simply brought together supply and demand in one figure.

As shown, only one region: $R_{s}=R_{1}$ provides stability.

\section{PART III: Goss' Paper 2002}

Goss wrote [6] that "technological" and "engineering" developments in shipping had a more serious role than economics, prior to $1960 \mathrm{~s}$. The original endeavor-going back to 1663, 1767 and 1928, (steam replaced sails and diesel steam)—was to reduce "navigational risk". Goss mentioned Buxton (in: 1987, 1993, 


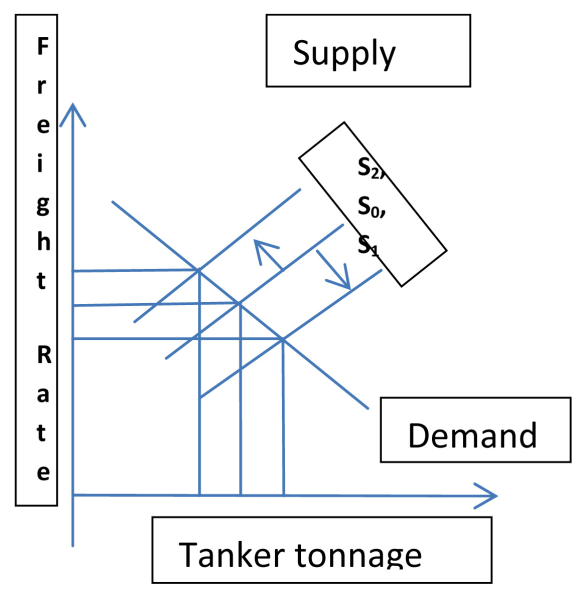

Figure 7. Prof. Talley's figure to exhibit cycles a la Zannetos. Source: author.

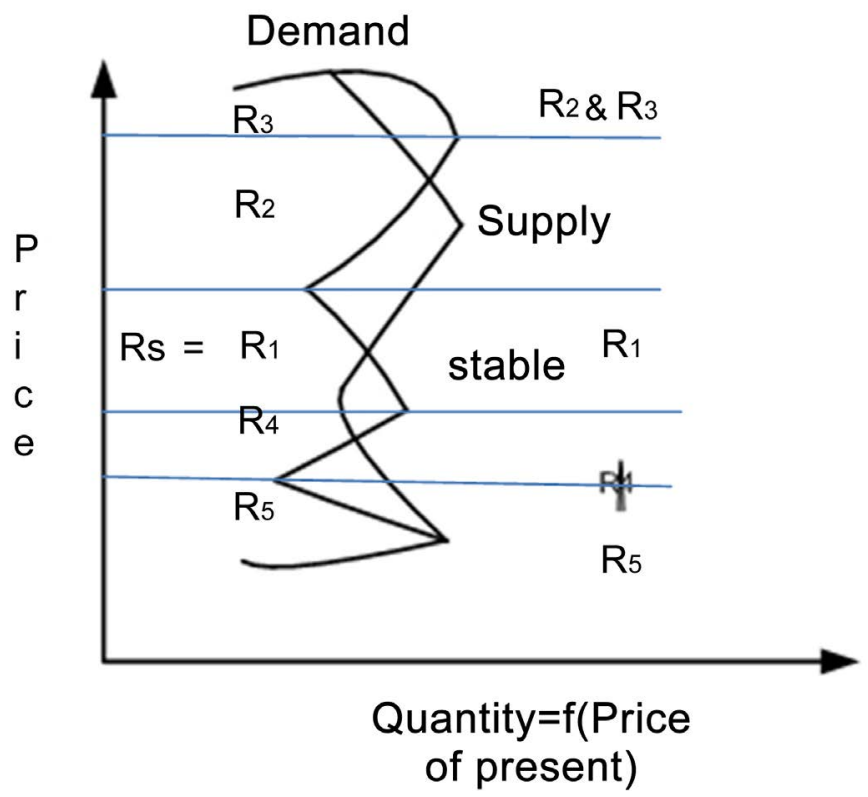

Figure 8. Zannetos equilibrium of tanker market and stable etc. regions. Source: author.

1998), who dealt with technological progress in the design of ships and propulsion. Goss also mentioned containerization and Brunel, who invented the 'cube law' allowing the construction of larger ships. So, Engineers were the pioneers in shipping economy.

Goss also counted Thorburn (1960 [13]), who argued that the economies in ships are often limited by ship's turnaround time (due to ship's length and number of cranes): i.e. "the total cargo handling" depends on the cube of ship's length, and "ship's turnaround time" depends on the square of ship's length...

Economics confined in Universities; international trade theory assumed zero transport cost... In shipping, supply was analyzed by accountants, and demand by marketing people, or by brokers; so then there was no need for shipping micro-economists.

Moreover, British shipowners developed a secret long-standing strategy... and 
prevented IMCO (1959) to produce economic studies on conferences! This led UN to form UNCTAD (in 1964), and a "Committee on shipping". UNCTAD produced a series of economic studies criticizing certain common practices of shipping conferences for "fixing" freight rates...

Moreover, economic principles for construction, extension and operation of ports were unclear ${ }^{39}$. Goss admitted that Koopmans' work (1939) [1] was a serious piece of economic literature, and asked why Koopmans did not mention “accelerator mechanism"... Stopford [46] also omitted in his book's subsequent 2 editions (after 1988)...to mention acceleration...

Goss mentioned: Svendsen's work in 1958 (his Ph.D. product) [52]. But still Shipping had no substantial corpus of literature; and only one center of learning was (at Bergen). In 1958, shipowner Naess financed the establishment of the "Institute of shipping economics", where the liaison with "Norwegian Shipowners Association" was economist Seland J.

Goss argued that the relationship between "Norwegian shipowners Association" and Academia... contributed to the success of Norway's shipping, and for the 1984 foundation of NISR... (Norway's parallel international register).

Goss during 1960s mentioned the activity of a number of...entrepreneurs quasi economists; he called them "professional economists", acting in 1953 and more so by 1960s; these were involved in the management of 'shipping lines' and "shipbuilding" in UK.

The main problem was "ships' economic efficiency", and in particular "time (and cost) a ship spends in ports" (Goss [53]), and in "cargo-handling". Before long, English understood-after a visit in USA - that the answer was the containers; apropos Sir Ian Lloyd-manager of the "Clan and Union Castle lines"- understood this and became chairman of ICHCA ${ }^{40}$.

In 1963, Goss-with a degree in economics-joined UK Ministry of Transport as economic consultant on "shipping, shipbuilding and ports". This was a land-mark for him. His research program at once set: the 'effect of shipping on "balance of payments"'; the "optimal ship design"; the "size of ships, and the cost of ships' time".

Subsequently, a group formed, which named, by Pollock E, "maritime economists' group" to study ships and ports. At this time, we believe, the birthday certificate of this discipline issued, baptized also and receiving the title "Maritime".

Goss re-mentioned the work of: Svendsen (1958) [52]; and of Prof. Thorburn Th. (1960)'s [13], called it elegant; and of Dr. Sturmey S. (1962) [4], called it a policy oriented; and Ferguson A. et al. (1961) [54], on the "economic value of US Merchant Marine"41. At this time IMO established the "World Maritime Univer-

\footnotetext{
39"Norwegian Shipowners Association" commissioned a study to Omtvedt P. (in 1962) on ports. He applied "Queueing" theory and "Erlang distribution".

40"International cargo handling coordination association".

${ }^{41}$ This was a product of a study commissioned by "subsidized” line companies, but study's conclusions were against them!
} 
sity" (in 1983) in Sweden.

Goss was concerned with the economic techniques applied to Naval Architecture, represented by Benford (in 1963) at the University of Michigan, applying "economic engineering". In UK, Goss (1968 reprint 1970) [3] prepared 2 papers presented in the "Royal Institute of Naval Architects" (1965; 1967), which was experimenting with the "optimization of propeller and underwater hull".

The optimal ship for Goss was the most profitable, having the lowest long run cost. He dealt with the "discounted cash flow" method and taxation, which triggered a significant literature, where Prof. Marlow Pcontributed. Dr Buxton (in: 1987, 1993 \& 1998), of the "University of Newcastle upon Tyne", continued the American tradition in UK.

The situation in 1970s was satisfactory by producing: 2 Journals, MP \& M and ME \& L; 3 textbooks: McConville's J. (1999) [44]; Stopford's M (1988) [46] and Wergeland's T (1996) with Wijnolst N [55]; a bibliography ${ }^{42}$ (1995) [45]; a continuous number of conferences since 1976 in Piraeus, IAME's (1991) at Erasmus and at Lyon (1992) and thereafter after every 2 years till this day; a rapidly increasing literature on economics of safety, cost benefit analysis for FSA-Formal safety assessment, for which English are proud.

\section{PART IV: Maritime Economics Research, 2001-2012}

Talley (2013 [17]) recorded 297 papers published in discipline's 2 main journals ${ }^{43}$. These dealt with: Shipping economics: 115 papers (39\%); Port Economics: 126 (42\%); Logistics ${ }^{44}: 20$ (7\%) and Technical: 36 (12\%) i.e. safety, security, "port state control" and ships' air emissions; total $100 \%$. Notably, non-purely economic papers on "Safety", "Security", "Sea and Air pollution", "Climatic change" and "Piracy", appeared under "technical", based on the idea that shipping may have a negative impact on/from them.

Port economics produced a larger number of papers $(+3 \%)$. The most popular subject in Port economics was: port performance with 53 papers. In shipping economics from 78 papers, 46 dealt with shipping performance and management and 32 with finance.

Almost half (45.5\%) of the papers were characterized "descriptive-legalistic-historical"... Mathematical (plus probability) papers were only 107 (=38\%). Talley (2013 [17]) found also 3 further gaps in maritime research: issues on "shippers", on "networks" and on "chains". He ignored the 3rd maritime journal: "Shipping and Transport Logistics" launched in 2009 (Hong Kong).

\footnotetext{
${ }^{42}$ Goss remarked that subjects like competition, contestability, cycles, marginal cost and papers from Australia, did not appear. Also Svendsen's papers were not his, but about him.

${ }^{43}$ Maritime Policy \& Management: 2001-2012 and Maritime Economics \& logistics: 2002-2012.

${ }^{44}$ Logistics is a "bridge-field"-mostly of economic nature- connecting "ships" with "ports" and their hinterlands. This attracted the intense attention of maritime economists conceiving transport cost in its entirety from point of production to point of consumption-including information flow. This is a broader concept for "sea transport efficiency" than freight rate. Two maritime economic journals adopted the term "logistics" in their title.
} 


\section{PART V: Marine Economics Defined}

Goss (2002 [6]) and Button (2005 [21]) "flirted" with Marine Economics. To clear this issue: Marine economics deals with 22 industries (Table 1), including Maritime Economics!

Maritime economies contributed to world's turnover $\$ 519 \mathrm{~b}$ in $2004(\sim 37 \%)$. Shipping grew faster since 1999 (+22\%). Maritime tourism is also important, contributing \$209b (15\%); “Marine fisheries" \$206b ( 15\%); "offshore oil and gas" $\$ 113 \mathrm{~b}(\sim 8 \%)$. Marine resources managed by 3 industries and Marine fisheries by 4 , contributing a total of $\$ 323 \mathrm{~b}(\sim 23 \%)$.

Table 1. Activities of Marine Economics: \$ turnover \% (2004).

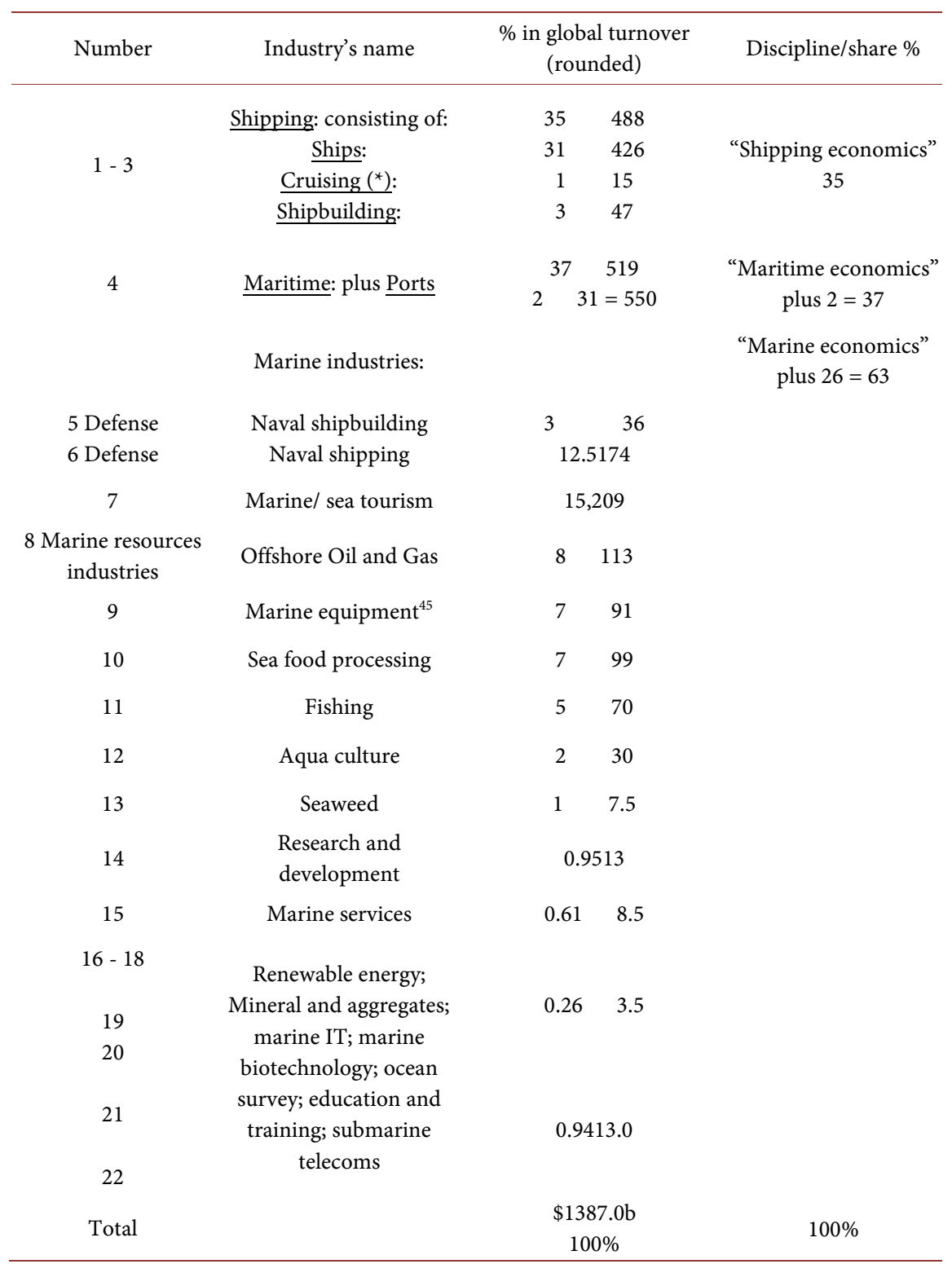

Source: Stopford (2009 [46]). (*) A neglected topic, dealing with "floating hotels", revives at times; Maritime economists criticized for neglecting it.

${ }^{45}$ From shipbuilding one may subtract marine equipment, if calculated twice. 


\section{PART VI: The Tanker Market, 1985-2010}

\subsection{Market Fluctuations}

The tanker market reached a low in 1985; recovered in 1989. Till 1992, the recovery led owners to heavy ordering - a classical reaction (1988-1991) -reaching $55 \mathrm{~m}$ dwt ( $18 \%$ of existing fleet). Overaged tankers were not scrapped. The rather small shipbuilding capacity of $15 \mathrm{~m}$ dwt, increased, soon, to $33 \mathrm{~m}$; this led to higher shipbuilding prices (e.g. a VLCC priced $\$ 90$ in 1990 from $\$ 40 \mathrm{~m}$ ).

A growing demand was satisfied from shorter-hauls and the VLCCs. Deliveries of over-ordered tankers led to recession-lasting 3.5 years (to mid-1995) - and to heavy scrapping (ships $>22$ years) - another classical reaction. Scrapping led to the improvement of freight rates: a VLCC earned \$80,000/day (Dec. 2000). But a recession in 2001 in certain economies by 2002, led to another slump, where a VLCC earned only \$10,000/day now. Oil imports by 2003 expanded-due mainly to China-and market improved till 2007.

The same pattern emerged in 2008 and in 2009 , where a VLCC earned $\$ 88,400$ (2008), and \$28,000/day (2009). We counted 7 peaks between 1998 and 2010 (shown by the BDT Index).

\subsection{The Fleet}

In Jan. 2003, 3562 tankers existed of a total of $306 \mathrm{~m} \mathrm{dwt}$, and 364m (+19\%) in 2007. Moreover, 56\% (in dwt) of the existing fleet was in sizes of 120,000 dwt and over (counting ships of over 10,000 dwt). The tanker fleet was stagnant between 1991 and 2002, varying from $299 \mathrm{~m} \mathrm{dwt} \mathrm{(1991)} \mathrm{to} 306$ (2002) (+2.3\%).

The independents ${ }^{46}$ owned 2846 tankers of $\sim 246 \mathrm{~m}$ dwt (81\% of total) (2003); oil companies owned 179 tankers of $\sim 20 \mathrm{~m}$ dwt (6\%). Average age was $13.2 \mathrm{ys}$ for independents, 14.5 ys for oil companies, but 19.4 ys for the State fleets (311 tankers and $\sim 17 \mathrm{~m}$ dwt...). In addition, almost $1 / 2$ of the tankers had (2003) double hulls.

\subsection{The Chartering Pattern of Main Charterers (2002)}

Ten of the major oil companies concluded-in 2002-3294 fixtures employing $\sim 70.5 \%$ of tonnage or $390 \mathrm{~m}$ dwt. Shell was first with a $12.24 \%$ share. 20 companies concluded 4471 fixtures employing $\sim 553 \mathrm{~m}$ (Table 2).

\subsection{Tanker Sizes, Ages, Flags and Volume of Time Charters, 1999-2002}

Twenty companies chartered $33 \mathrm{~m}$ dwt in time charters or $\sim 6 \%$ of total dwt in 2002 (Table 2). So, Oil charterers abandoned their almost exclusive preference in the past in long term charters. $\sim 74 \%$ of the time chartered vessels in dwt by ${ }^{46}$ Ten of them (having 31\%) were (rounded): Frontline $17 \mathrm{~m} \mathrm{dwt}$; Mitsui $\sim 11$; Teekay 9; World-Wide 7; Bergesen 5; Tanker Pacific Mangt 5; AP Moller 5; NYK 5; and Angelicoussis 4; owning 440 tankers of total 74m dwt. Another 10 (having 57\%) and 339 tankers were (rounded): Vela, 5 mdwt; China, 5; NITC, 4; Exxon-Mobil, 3; Petrobras, 3; Shipping Corp. of India, 3; KOTC, 3; Sovcomflot, 3; Nat. Ship. Saudi A, 3; Shell, $2.5=\sim 34 \mathrm{~m}$ dwt. 
Table 2. Oil companies chartering pattern, 2002.

\begin{tabular}{|c|c|c|c|}
\hline Company & Fixtures No & Dwt million-rounded & Share \% \\
\hline BP (4) & 482 & 49 & $8.80=\sim 42$ \\
\hline Shell (1) & 581 & 68 & 12.24 \\
\hline Exxon Mobil (2) & 534 & 59 & 10.65 \\
\hline Chevtex (3) & 506 & 58 & 10.50 \\
\hline Total (5) & 396 & 45.5 & 8.23 \\
\hline Vitol (6) & 249 & 29 & 5.19 \\
\hline $\operatorname{IOC}(7)$ & 146 & 24 & 4.38 \\
\hline Vela (8) & 66 & 19.5 & 3.53 \\
\hline Navion (9) & 135 & 19.4 & 3.50 \\
\hline Karran (10) & $199=3294$ & $19=\sim 390$ & $3.46=\sim 70.5$ \\
\hline Reliance (11) & 106 & 19 & 3.46 \\
\hline S-Oil (12) & 73 & 19 & 3.45 \\
\hline Sun (13) & 126 & 17 & $3.01\left(^{*}\right)$ \\
\hline Sinichem (14) & 122 & 16.3 & 2.94 \\
\hline Alpine (15) & 138 & 16 & 2.87 \\
\hline Valero (16) & 193 & 16 & 2.85 \\
\hline SK (17) & 108 & 16 & 2.82 \\
\hline Repsol (18) & 151 & 15 & 2.75 \\
\hline СРC (19) & 61 & 15 & 2.74 \\
\hline LG Caltex (20) & $99=4471$ & $15=\sim 553 \mathrm{~m}$ & $2.63=100$ \\
\hline
\end{tabular}

Source: Psaropoulou (2004) [56]; data coming from Lloyd’s Shipping Economist, Aug. 2003. $\left(^{*}\right) 13$ companies with shares $\geq 3 \%$.

the larger 20 oil companies, in 1999-2002, were: Aframax ( 54\%; 80k-120k), VLCC ( 17\%; 200-320k) and ULCC (320 - 550) 3\%.

"Entry" became more difficult by 2002, as charterers-by majority-looked for very large vessels. Entry became more difficult as the 20 top oil companies chartered younger ships for the fear of a marine accident by the old ones; $72 \%$ of the time chartered tonnage (652 fixtures) in dwt, between 1999 and 2002, was for ships $\leq 10$ years. But ${ }^{47}$ also a $\sim 23 \%$ was over 21 years of age. As for the choice of flag, out of 38 flags in 1999-2002, Liberia had lion's share with $\sim 23.5 \%$ of total dwt time-chartered in 652 time charters of $\sim 87 \mathrm{~m}$, followed by Norway NIS $(\sim 14 \%)$ and Panama ( 14\%).

Six oil companies had a share each varied from $4.7 \%$ to $9.4 \%$ ("Skaugen") in time-chartered dwt, 1999-2002. These shares, of $\sim 11.52$ million dwt max., we believe, can affect demand and thus freight rates, if removed from the market. The $\mathrm{CR}_{4}$ is $31 \%$ and the $\mathrm{CR}_{20}$ is $\sim 71 \%$ (1999-2002). By 2003, 126 companies owned $2.43 \mathrm{~m} \mathrm{dwt} \mathrm{each} \mathrm{on} \mathrm{average,} \mathrm{and} 28$ ships (Table 3 ).

${ }^{47}$ Owned by... State companies. 
Table 3. The activity of 20 oil companies in 2002 in time charters.

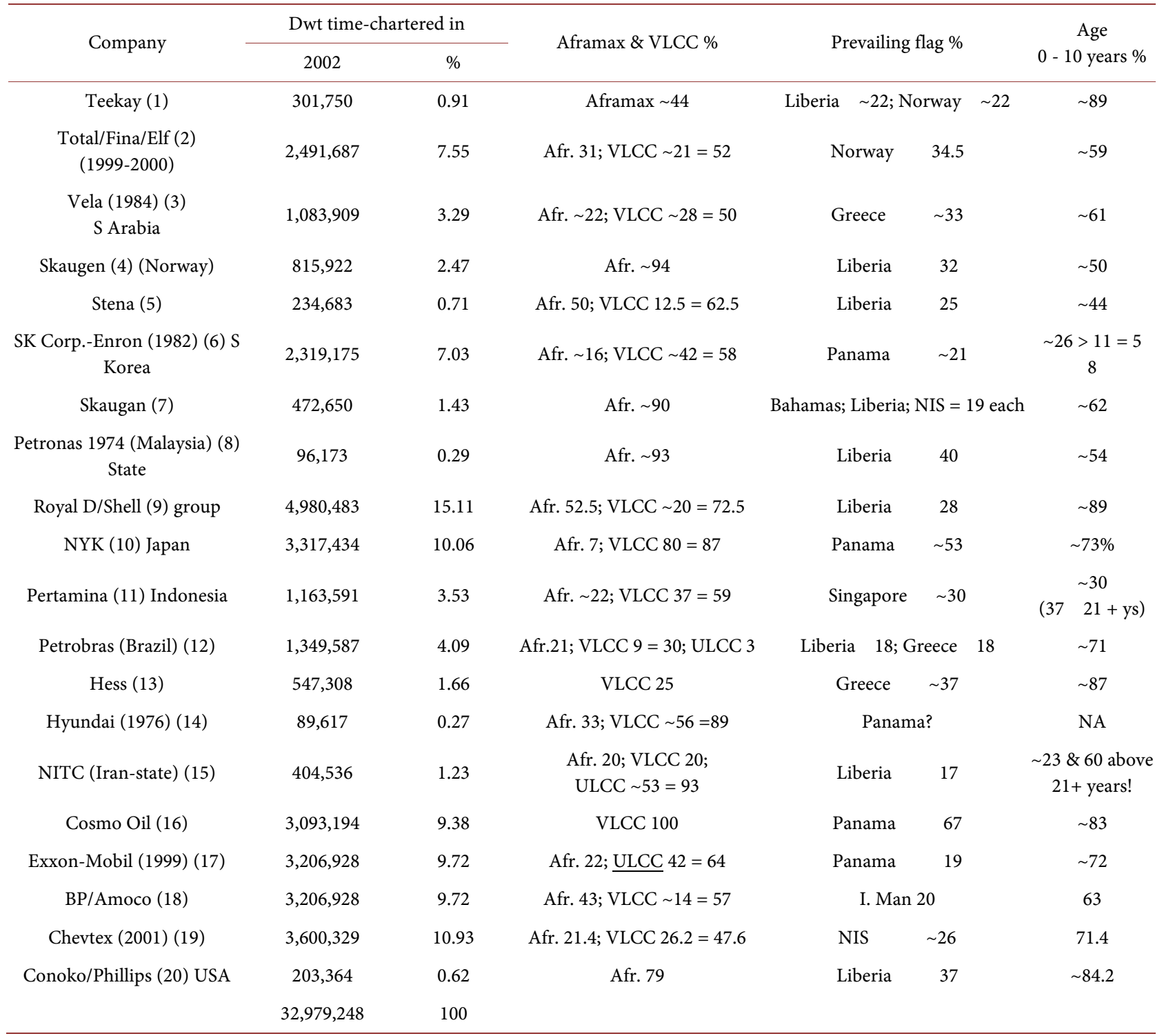

Source: Data from Psaropoulou (2004) [56]. Worth noting are the $\%$ above $50 \%$ of $14 / 20$ of oil companies for ships aged $\leq 10$ years of age (highlighted).

Forty three $\%$ of time charters lasted 3 months; $16 \% 12$ months; $3 \%>12$ months and 39\% were trip charters (out of 685 fixtures found in "Lloyd's Shipping Economist"). So the policy of oil companies to boost supply of tonnage via long term time charters has ended. Moreover, Stopford (2009) [46] showed that from $120 \mathrm{~m}$ dwt owned by independents in charters in 1973, $100 \mathrm{~m}$ or $\sim 83 \%$ was in period, while in the spot market were only $20 \mathrm{~m}$ dwt or $\sim 17 \%$. By 1983 the tanker trading in spot market was $140 \mathrm{~m}$ out, of $170 \mathrm{~m}$, or $82 \%$ ! By 2007, period charters were $\sim 50 \mathrm{~m}$ dwt out of $150 \mathrm{~m}$ i.e. $30 \%$.

\section{Concluding Remarks}

Oil companies ceased eventually to be a monopsony after 1991-by reducing their $\%$ own participation from $40 \%$ to $6 \%$ in time charters and in capacity 
gradually by 2002-2007. This was due to the preceding long crisis, 1991-2002, the extensive scrapping and laying-up, and the fear to be involved in a major marine accident. They chartered-by majority—tankers of up to 10 years of age. The totality of time fixtures was for up to one year: 59\% (1999-2002), where 39\% were trip charters ${ }^{48}$ (related also to spot market).

Oil companies preferred-by majority-to use Aframax and VLCC. Flags-by majority-belonged to flags of convenience. More frequent scrapping and lay-up took place; a volatile and unpredictable market, coupled with an unpredictable and volatile oil price ${ }^{49}$; competition from schist oil and gas appeared; perhaps fewer marine accidents; and when rates increased, orders increased. Deliveries-after construction time-diminished rates and the orders stopped (except renewals), and scrapping and lay-up increased (one tanker cycle).

The same way followed the $2^{\text {nd }}$ cycle. Demand is unpredictable and supply is spontaneous. But, timing is the King (Goulielmos and Goulielmos, 2009 [57]).

Vessel is not the firm and shipping markets are not near perfect competition. The complete absence of monopoly is a more realistic assumption for shipping, provided demand curve is also horizontal for a single shipping firm. McConville (1999) [44] - to the contrary-argued that tankers area good approximation of the neo-classical perfect competitive market...

Given safety regulations in shipping, (mainly ISM Code), and the tentative closer relationships of large independent companies with major oil companies, and shipping firms' promotional efforts, homogeneity in ships is a property in degrees.

Moreover, if services were all homogeneous, then age should play no role...but it does. Also ship's size plays a role, while it should not. Moreover, the "fear" of a marine accident plays a role, but it should not...Perfect information $^{50}$ is disputed, given also the secretive character of shipping. Hicks in 1946 argued that "perfect foresight" used to be... a toy in the hands of economists to play with...

Most consider free shipping entry and exit to be feasible, but in real life are not (e.g. "Hajin's exit from containerships carried-out with a substantial cost). Consider also the enormous capital needs to enter the tanker market with the most popular sizes-Aframax and VCLC. The entry into shipping industry-with "roughly" identical" services-is free, but one should have the knowhow and the required own capital (20\% - 40\% of price).

As time passes-by the above possibility becomes more difficult, as funds re-

\footnotetext{
${ }^{48}$ Method of employment of ships comparable with voyage - and time-chartering.

${ }^{49}$ In 2007 the price of oil (Brent) varied from $\sim 66$ to $\$ 92$ (Jan.-Dec.).

50"Perfect foresight": a condition abandoned.

${ }^{51}$ Ship's age plays now a serious role in chartering, especially when ships are plenty. There is the perception of charterers that there is a higher probability-if she is older than 10 years of age-to "create" a marine accident. This tendency to a marine accident we know that is a function of age, human error and maintenance. But charterers prefer also shorter time charters with older ships, and younger ships for longer charters... Theoretically, the ship services of vessel $\mathrm{x}$ are identical to ship service of vessel y, but in charterers' eyes things are different. Also, major charterers have their own requirements for safety on top of those of ISM Code. So, safety requirements destroy homogeneity.
} 
quired increase, given that both average ship size $\mathrm{e}^{52}$ and value increase. Banks formed syndications to cope with the higher amounts emerged-single loans increased 10 times reaching $\$ 100 \mathrm{~m}$ on average 10 - 15 years ago. Banks had to protect themselves from the increased risk, which followed the size of the ships. There are also shipping recessions and depressions when prices of ships change dramatically.

The identical production processes need also examination to say that they exist, because companies are unfamiliar with tankers in upper sizes and need familiarization at beginning. $\mathrm{MR}=\mathrm{AR}=$ Freight rate; $\mathrm{MC}=\mathrm{MR} ; \mathrm{MC}=$ freight rate but per voyage.

Most economists consider also the number of owners (of tanker space for the transport of crude oil) for competition; this in tankers is large-we estimate them roughly 1200 companies managing 3600 ships worldwide having "on average" 3 vessels. It is plausible to assume them to be private by majority. So, an oligopoly ${ }^{53}$ is excluded, but one must be careful and examine supply and demand conditions, separately in shipping per size, per age, per flag and per phase of the cycle, to be sure.

As argued by Chandler, (1990), [58], p. 92), oil companies from a monopoly became oligopoly, and OPEC (in 1960) from a trade organization became a cartel (in 1973), i.e. a legal monopoly, consisting of 10 governments. OPEC determines the price of oil by regulating supply.

Zannetos (1972) [59] argued that an economy of scale is created only by vessel's increased size. In bunkers, e.g. oil companies provide volume discounts to firms. But Zannetos [2] needed the above to dilute the potential of monopsony power of oil companies, and to strengthen his arguments in favor of the efficiency of the competitive market, which Evans (1994) [15] could not find in the long run.

Zannetos missed the point by saying that by (expanding the) size of tankers, this will not destroy the workings of the free market mechanism; it is the size of the firm which matters more, we reckon, which is made up by a number (a set) of vessels. We saw large companies to be in position to expand supply massively, (million $\mathrm{dwt}$ ), and as a result reduce freight rates, something inconsistent with perfect competition.

Heaver (1972) [60] argued that the "tanker charter market was an example of economists' imperfect markets, because: there was only a limited number of ${ }^{52}$ At the time of Zannetos (01/01/1959) (ships were of $\left.6000+\mathrm{dwt}\right)$ : existed 23 owners-the oil com-
panies-owned 872 vessels ( $\sim 1.04 \mathrm{~m} \mathrm{~T}-2 \sim 32 \%)$; the remaining 34 oil companies owned $1.26 \%$; 16
owners-the independents ( 11 were Greeks)-owned 315 ships and the remaining independent
owners owned 1398 ships; the "Government commercials" owned 84 ships (a total 2703 ) of $3,167.2$
T-2. But even then Shell had the higher share ( $8.25 \%)$ in the number of ships totaling 207 T- 2 .
${ }^{53}$ A matter, which destroys the homogeneity of shipping services is the degree of their safety, though
made compulsory (IMO, ISM Code, 1998; 2002) for all companies. Safety and security (ISPS code,
2004) increased the costs of "loyal" shipowners. Certain shipowners took it as an opportunity to dif-
ferentiate their services by acquiring also ISO standards...Charterers, however, took the matter of
safety as an obligation of shipowners and demanded it (via charter parties). The safety issue made
obviously free entry even more difficult. 
ships available for charter $(4 \%-18 \%)$ at any one time-something more acute in booms, as argued by Zannetos [2] — and the market was dominated by a limited number of very large buyers (the oil companies) (italics added)".

Worth noting is that when Zannetos calculated the 1st differences of the 119 monthly averages of spot rates, thought that their distribution followed-at first glance-a "random walk". This, however, would negate his theory concerning the systematic influence of price-elastic expectations... Further research is thus required (Goulielmos and Psifia, (2007), [61]).

\section{Conflicts of Interest}

The authors declare no conflicts of interest regarding the publication of this paper.

\section{References}

[1] Koopmans, T.C. (1939) Tanker Freight Rates and Tankship Building: An Analysis of Cyclical Fluctuations. Haarlem (De Erven F. Bohn N V), Holland.

[2] Zannetos, Z.S. (1966) The Theory of Oil Tankships Rates: An Economic Analysis of Tankship Operations, MIT Press, Cambridge.

[3] Goss, R.O. (1968) Studies in Maritime Economics, Collection of 7 Papers. Cambridge University Press, Cambridge (Reprinted 1970).

[4] Sturmey, S. (1962) British Shipping and World Competition. Athlone Press, London (Republished 2010).

[5] O'Loughlin, C. (1967) The Economics of Sea Transport. Pergamon Press, London.

[6] Goss, R.O. (2002) An Early History of Maritime Economics. Maritime Economics \& Logistics, 4, 390-404. https://doi.org/10.1057/palgrave.ijme.9100052

[7] Evans, J.J. and Marlow, P.B. (1990) Quantitative Methods in Maritime Economics. 2nd Edition, Fairplay Pubs, London.

[8] Goodwin, E.M. and Kemp, J.F. (1979). Marine Statistics: Theory and Practice. Stanford Maritime, London.

[9] Goss, R.O. (ed.) (1977) Advances in Maritime Economics. Cambridge University Press, Cambridge.

[10] Goulielmos, A.M. (2017) Strategies in “Shipping Business Management”. Modern Economy, 8, 1211-1229. https://doi.org/10.4236/me.2017.810083

[11] Goulielmos, A.M. (2017) The Great Achievement of Greek-Owned Shipping (1946-2017) and Keynes' Animal Spirits. Modern Economy, 8, 1186-1210. https://doi.org/10.4236/me.2017.810082

[12] Stokes, P. (1992) Ship Finance: Credit Expansion and the Boom-Bust Cycle. London of Lloyds Press, London.

[13] Thorburn, T. (1960) Supply and Demand of Water Transport: Studies in Cost and Revenue, Structure of Ships, Ports and Transport Buyers with Respect to Their Effects on Supply and Demand of Water Transport of Goods. The Business Research Institute at the Stockholm School of Economics, Stockholm.

[14] Downard, J.M. (1984) Managing Ships. Fairplay Publications, London.

[15] Evans, J.J. (1994) An Analysis of (the) Efficiency of the Bulk Shipping Markets. Maritime Policy \& Management, 21, 311-329. 
https://doi.org/10.1080/03088839400000055

[16] Veenstra, A.W. and De La Fosse, S. (2006) Contributions to Maritime Economics Zenon S, Zannetos, the Theory of Oil Tankship Rates. Maritime Policy \& Management, 33, 63-73. https://doi.org/10.1080/03088830500513444

[17] Talley, W.K. (2013) Maritime Transportation Research: Topics and Methodologies. Maritime Management \& Policy, 40, 709-725. https://doi.org/10.1080/03088839.2013.851463

[18] Binkley, J.K. and Bessler, D.A. (1983) Expectations in Bulk Ocean Shipping: An Application of Autoregressive Modeling. Review of Economics \& Statistics, 65, 516-620. https://doi.org/10.2307/1924201

[19] Norman, V.D. (1979) Economics of Bulk Shipping. Institute of Shipping Research, Bergen.

[20] Glen, D.R. (1990) The Emergence of Differentiation in the Oil Tanker Market, 1970-1978. Maritime Policy \& Management, 17, 289-312. https://doi.org/10.1080/03088839000000034

[21] Button, K. (2005) Shipping Economics: Where We Are and Looking ahead from an Institutional Economics Perspective. Maritime Policy \& Management, 32, 39-58. https://doi.org/10.1080/0308883042000326111

[22] Coase, R.H. (1998) The New Institutional Economics. American Economic Review, 88, 72-79.

[23] Rochdale (1970) The Rt. Hon. the Viscount (Chair). Report of the Committee of Inquiry into Shipping, London.

[24] Goss, R.O. (1965) Economic Criteria for Optimal Ships Designs. Transactions of the Royal Institution of Naval Architects, 107, 581-596.

[25] Goss, R.O. and Jones, C.D. (1971) The Economics of Size in Dry Bulk Carriers. HMSO, London.

[26] Goss, R.O. (1967) Towards an Economic Appraisal of Port Investments. Transport Economics \& Policy, 1, 249-272.

[27] Goss, R.O. (1967) The Turnaround of Cargo Liners and Its Effect on Sea Transport Costs. Transport Economics \& Policy, 1, 75-89.

[28] Goss, R.O. (1990) Economic Policies and Seaports, Parts 1, 2, the Economic Functions of Seaports. Maritime Policy \& Management, 17, 207-219. https://doi.org/10.1080/03088839000000028

[29] Brooks, M.R. and Pallis, A.A. (2012) Port Governance. 491-516.

[30] Goss, R.O. (1990) Economic Policies and Seaports, Parts 3, 4: Are Port Authorities Necessary? Maritime Policy \& Management, 17, 257-271. https://doi.org/10.1080/03088839000000032

[31] Dekker, S. and Verhaeghe, R.J. (2012) Port Investment and Finance. 623-637.

[32] Goss, R.O. (1972) Comment in: Shipping Management Proceedings. Lorange P and Norman, Bergen.

[33] Goulielmos, A.M. (2013a) An Econometric Analysis of the Impact of Vessel Size on Weekly Time Charters: A Study in Volatility (Panamax and Cape). Transport Economics, 40.

[34] Heaver, T.D. (2012) The Evolution of Maritime Economics, in the Blackwell Companion to Maritime Economics. Wiley-Blackwell, Hoboken, 16-33. https://doi.org/10.1002/9781444345667.ch2

[35] Goss, R.O. (2003) Maritime Insurance and Economic Welfare. Maritime Policy \& 
Management, 30, 357-362. https://doi.org/10.1080/0308883032000145573

[36] Marx, Jr. D. (1953) International Shipping Cartels. Princeton University Press, Princeton.

[37] Marshall, A. (1920) Principles of Economics. 8th Edition, MacMillan, London.

[38] Henderson, J.M. and Quandt, R.E. (1958) Microeconomic Theory: A Mathematical Approach. McGraw-Hill Kogakusha, Tokyo.

[39] Zannetos, Z.S. (1976) WP 880: "Economic Theory and Ocean Transportation of Oil. MIT, Cambridge.

[40] Couper, A.D. (1999) Voyages of Abuse: Seafarers, Human Rights and International shipping. Pluto Press, London.

[41] Besanko, D., Dranove, D., Shanley, M. and Schaefer, S. (2013) Economics of Strategy. 6th Edition, Wiley, Hoboken.

[42] McConville, J. (1998) Editorial, Twenty-Five Years on. Maritime Policy \& Management, 25, 1-2. https://doi.org/10.1080/03088839800000041

[43] Lerner, A.P. (1934) The Concept of Monopoly and the Measurement of Monopoly power. The Review of Economic Studies, 1, 157-175.

[44] McConville, J. (1999) Economics of Maritime Transport: Theory and Practice. Institute of Chartered Shipbrokers, London.

[45] McConville, J. and Rickaby, G. (1995) Shipping Business and Maritime Economics, an Annotated International Bibliography. Mansell, London.

[46] Stopford, M. (2009) Maritime Economics. 3rd Edition, Routledge, London. https://doi.org/10.4324/9780203891742

[47] Goulielmos, A.M. (2013) Oil Transport Management. In: Venus Lun, Y.H., Hilmola, O.-P., Lai, K.-H. and Cheng, T.C., Eds., Shipping and Transport Logistics, Springer, Berlin, 27-62.

[48] Hirschey, M. Pappas, J.L. and Whigham, D. (1995) Managerial Economics. European Edition, The Dryden Press, London.

[49] Martin, S. (2010) Industrial Organization in Context. Oxford University Press, Oxford, 167.

[50] Morrison, P.C.J. (2001) Market and Cost Structure in the US Meat Packing Industry. Review of Economics and Statistics, 83, 531-540. https://doi.org/10.1162/00346530152480171

[51] Zannetos, Z.S. (1973) Persistent Economic Misconceptions in the Transportation of Oil by Sea. Maritime Policy \& Management, 107-118.

[52] Svendsen, A. (1958) Sea Transport and Shipping Economics, Bremen.

[53] Goss, R.O. (1983) Ships' Costs: A Review Article. Maritime Policy \& Management, 10, 127-131. https://doi.org/10.1080/03088838300000018

[54] Ferguson, A.R., et al. (1961) The Economic Value of the US Merchant Marine. Transportation Center, Northwestern.

[55] Wergeland, T. and Wijnolst, N. (1966) Shipping. Delft University Press.

[56] Psaropoulou, V. (2004) Policy on Tanker Time Charters. Master's Thesis, Univ. of Piraeus, Dept. of Maritime Studies. http://ag@unipi.gr

[57] Goulielmos, A.M. and Goulielmos, M.A. (2009) The Problem of Timing in Decisions to Buy or to Charter a Vessel. Transport Economics, 36, 261-286.

[58] Chandler, A.D. (1990) Scale and Scope: The Dynamics of Industrial Capitalism. The Belknap Press, Harvard University Press, Cambridge. 
[59] Zannetos, Z.S. (1972) Market and Cost Structure in Shipping. Institute for Shipping Research and Maritime Research Center, Hauge.

[60] Heaver, T.D. (1972) Market and Cost Structure in Shipping. Institute for Shipping Research and Maritime Research Center, Hauge.

[61] Goulielmos, A.M. and Psifia, M-E. (2007) A Study of Trip and Time Charter Freight Rate Indices: 1968-2003. Maritime Policy \& Management, 34, 55-67. https://doi.org/10.1080/03088830601103418

[62] Goulielmos, A.M. (2001), Matters of Definition: Maritime Economics Revisited. Essays in Honor of Late Prof. D. Kodosakis, University of Piraeus. 


\section{Appendix: Button's Critique}

Button (2005) [21] influenced by Coase [22] wanted to bring "institutional economics" ${ }^{\text {"54 }}$ in maritime economics. Moreover, he scanned the "premier ${ }^{55}$ general economics journals", 1975-2005, and he found few papers dealing with shipping (italics added)... He looked also if shipping economics kept abreast of some of the larger shifts taking place in the study of economics...He argued that much of what we do know tends to reflect short term market considerations... whereas, other equally important -long-term economic and related social and political effects-are missing...

For Button, only McConville J. (1999 [44]) provided a thorough... but neoclassical book, in Maritime Economics. But one must go beyond this, he argued. He further claimed that the proper approach of maritime economists should be "more holistic"-moving beyond conventional, largely neoclassical, economic tools, as so far. Shipping is a network industry ${ }^{56}$.

He offered a fragmented survey of the way economists treated shipping issues over a 10 year period. Some of the weaknesses in the understanding of shipping markets -including the implications from regulating them, and how actors decide-"are long standing and can be seen as generic challenges" in economics.

Button (2005 [21]) implicitly wanted to show-off the superiority of "American maritime economists"; idea to which Talley latter (2013 [17]) subscribed. Button [21] was also confused over the terms: shipping, maritime and marine economics. Goulielmos (2001) [62]) cleared-these terms-out ${ }^{57}$ and triggered Goss' paper [6].

Button argued that "in a very few instances maritime problems were at the root of new economic thinking". Maritime economics had also to use mathematics, as this was done in economics by Friedman (in 1991), and to increase sophistication". Maritime economists are forgiven because time is needed to understand shipping economics, and transportation, and the related environmental issues... (bolds added).

"Shipping played a limited role in the development of economic thinking and it was a rather recipient of ideas than a generator of them". Goss (2002 [6]) mentioned only for providing an "early history of the development of shipping

\footnotetext{
${ }^{54}$ Taking intoaccount institutions, land ownership, and property rights. This emphasizes the role of social, political and economic organizations in determining economic events. Theories advanced in 1874-1948, by Veblen, Mitchell and Myrdal. Coase joined in 1998 with his paper in the "American Economic Review".

${ }^{55}$ We found, in Economic Journal, 1971, two small books reviews: Lorange and Norman's "risk preference patterns among Scandinavian tankship owner", pp. 48: authors were criticized for drawing a not profound conclusion; and Norman's "a portfolio selection model of shipping behavior", pp. 57, where author criticized for his empirical tests leading to doubtful results, but..

${ }^{56}$ Meaning to connect shippers, carriers and ports together = i.e. a "chain" (Talley, 2013 [17]).

${ }^{57}$ Known in USA as "Sea Affairs", meaning "Sea economics", but not restricted to. It cares about sea environment, exclusive economic zone-EEZ and activities taking place on-and inside-coast and sea (Chinese determine this zone 20 kilometers in- and out-of coast). This branch was the result ofthe "Law of the Sea" (1982), giving the right to coastal nations to exploit sea resources: manganese rocks, oil, gas, fish etc. Sea is a nations' dual economy.
} 
economics"... and Thorburn (1960 [13]) as "the classic good book to economic thinking on maritime transport in 1960s, attracting the acceptance of many shipping economists"... 